\title{
A PROTEÇÃO DA UNIÃO ESTÁVEL PUTATIVA NOS REGIMES PREVIDENCIÁRIOS PÚBLICOS
}

\author{
Christiane Cruvinel Queiroz
}

ISSUE DOI: $10.21207 / 1983.4225 .253$

\section{RESUMO}

O presente trabalho irá tratar da temática do benefício previdenciário de pensão por morte devido ao companheiro do segurado falecido, na hipótese de união estável putativa, no âmbito dos regimes geral e próprio de Previdência Social. Para tanto, será analisada a construção jurisprudencial de nossos Tribunais Superiores que têm promovido modificações no conceito da união estável e seus desdobramentos restritivos ao caráter protetivo da Previdência Social, que não se coaduna com uma teoria do Direito fundada numa comunidade de princípios valorativos dos direitos fundamentais, dentre eles, o da dignidade da pessoa humana.

Palavras-chave: Pensão por morte. União estável putativa. Dignidade da pessoa humana.

\section{INTRODUÇÃO}


O presente trabalho, valendo-se do método dedutivo, incursionará na temática do benefício previdenciário de pensão por morte devido ao companheiro ou companheira do segurado, nos casos de união estável putativa, nos regimes geral e próprio da Previdência Social brasileira.

Para tanto, iniciaremos uma breve abordagem da evolução da proteção social no Brasil e, após, discorrermos sobre a conceituação atual da união estável; investigaremos a construção jurisprudencial pátria do instituto da pensão por morte devida ao companheiro do segurado falecido, tanto no regime geral quanto nos regimes próprios, esses com os mesmos fundamentos principiológicos do primeiro.

Com efeito, atribui-se ao Direito Previdenciário a vanguarda na proteção da(o) companheira(o) do segurado falecido, antes mesmo que houvesse qualquer norma positivada que reconhecesse a união estável, com vistas à proteção e assistência material da(o) companheira(o) que manteve vínculo afetivo e dependência econômica com o ente falecido.

Os direitos protetivos dos então denominados "concubinos" é fruto de uma evolução dogmática e jurisprudencial que, a partir da metade do século XX, passou a reconhecer-lhes direitos na esfera obrigacional. A aplicação da legislação previdenciária, precipuamente no âmbito do regime geral de Previdência Social, ao longo do tempo, vem reconhecendo o caráter subjetivo do vínculo do companheiro ou companheira, para assegurar a obtenção dos benefícios previdenciários, na qualidade de dependente do segurado, desde que comprovada a dependência econômica e a relação de união estável.

Em sentido oposto, o Supremo Tribunal Federal, ao julgar o Recurso Extraordinário 397.762-8/Bahia ${ }^{49}$, interposto pelo Estado da Bahia, de relatoria do Ministro Marco Aurélio, por maioria de votos, entendeu descabido o rateio de benefício previdenciário entre esposa e concubina, no âmbito do regime próprio de Previdência Social, procedendo-se à análise do instituto da união estável sob o seu aspecto meramente objetivo.

A Corte Suprema firmou entendimento acerca da necessidade de distinção dos institutos companheira e concubina, a fim de reconhecer a proteção do Estado à união estável somente nas situações legítimas que não contemplam a hipótese de concubinato.

49 Disponível em: <http://redir.stf.jus.br/paginadorpub/paginador.jsp?docTP= AC\&docID=547259>. Acesso em 7 de abril de 2014 . 
É nesse contexto que se buscará aqui uma reflexão sobre os avanços e retrocessos da proteção previdenciária da pensão por morte nos casos concretos de união estável putativa e traremos a teoria da "única resposta correta", de Ronald Dworkin, como marco teórico para a solução dos casos de proteção previdenciária na união estável putativa.

\section{O SISTEMA DE SEGURIDADE SOCIAL BRASILEIRO}

No Brasil, como na maioria dos demais países do mundo, a proteção social deu-se por meio de um processo lento de reconhecimento da necessidade de o Estado intervir para a proteção de contingências, partindo do assistencialismo para o seguro social e culminando com a Seguridade Social.

O conceito de Seguridade Social adveio com a instituição do Estado de Bem-Estar Social (welfare state), com o final da Segunda Guerra Mundial.

Willian Henry Beveridge, citado por Hovarth Junior (2003, p. 71), destaca que a Seguridade Social representa:

[...] uma parte da luta contra os cinco gigantes do mal: a miséria física, que o interessa diretamente; a doença, que é, muitas vezes, causadora da miséria e que produz ainda muitos males; a ignorância, que nenhuma democracia pode tolerar nos seus cidadãos; a imundície, que decorre principalmente da distribuição irracional das indústrias e da população; e contra o desemprego involuntário (ociosidade), que destrói a riqueza e corrompe os homens, estejam eles bem ou mal nutridos [...] Mostrando que a seguridade, pode combinar-se com a liberdade, a iniciativa e a responsabilidade do indivíduo pela sua própria vida.

No Brasil, o sistema de Seguridade Social consiste num conjunto integrado de ações de iniciativa dos poderes públicos e da sociedade, destinado a assegurar os direitos compreendidos nos três pilares: saúde, assistência social e previdência social. Foi instituído com a promulgação da Constituição Federal de 1988, a qual albergou no Capítulo II do Título VII, 
que trata da Ordem Social: a Saúde (artigos 190 a 200), a Previdência Social (artigos 201 e 202) e a Assistência Social (artigos 203 e 204).

A doutrina pátria é uníssona em asseverar que o direito à Seguridade Social é público subjetivo, irrenunciável, inalienável e intransmissível, oponível contra o Estado quando esse não cumpre as garantias constitucionais asseguradas para a satisfação das necessidades especiais dos cidadãos brasileiros.

Especificamente no que diz respeito às relações de Previdência Social, a Constituição Federal de 1988 organizou-a como um sistema de regime geral, contributivo e de filiação obrigatória, com observância dos critérios que preservem o equilíbrio financeiro e atuarial. Tem como objetivos, nos termos da lei, a cobertura aos seus beneficiários de infortúnios de doença, invalidez, morte, idade avançada, maternidade, proteção ao trabalhador em situação de desemprego involuntário, salário-família e auxílio-reclusão. Esses dois últimos para os dependentes dos segurados de baixa renda, e a pensão por morte do segurado, homem ou mulher, ao cônjuge ou companheiro e dependentes.

A Previdência Social no Brasil pode ser dividida em três componentes, tal como denominado por Pinheiro ${ }^{50}$, quais sejam: a) o regime geral de Previdência Social, previsto no Título "Da Previdência Social", artigo 201, Seção III do Capítulo II (Da Seguridade Social), inserta no Título VIII (Ordem Social) na Constituição Federal de 1988; b) os regimes previdenciários próprios dos servidores públicos prescritos na Seção II (Dos Servidores Públicos), artigo 40, do Capítulo VII (Da Administração Pública), do Título III (Da Organização do Estado) e, c) a previdência complementar privada prevista no artigo 202 da Constituição.

No que diz respeito aos princípios norteadores do sistema de Previdência Social pública, faz-se necessário termos em mente o seu papel fundante na edificação jurídica do tema objeto da presente pesquisa, posto que, nos dizeres de Espíndola, os princípios constituem-se “[...] um sistema de ideias, pensamentos ou normas por uma ideia mestra, por um pensamento chave, por uma baliza normativa, donde todas as demais ideias, pensamentos ou normas derivam, se reconduzem e/ou se subordinam". ${ }^{51}$

\footnotetext{
${ }^{50}$ PINHEIRO, Vinicius Carvalho. A experiência brasileira. In: Reformas dos Sistemas de Pensão na América Latina. MPAS, Coleção Previdência Social, 2001, v. 12. p. 28.

${ }^{51}$ ESPÍNDOLA, Ruy Samuel. Conceito de princípios constitucionais. São Paulo: Revista dos Tribunais, 1999. p. 47-48.
} 
Sem discorreremos sobre todas as concepções, importa trazer à tona duas grandes correntes doutrinárias que definem o conceito de princípio.

A teoria clássica do Direito Público define os princípios como os alicerces, as vigas-mestras do ordenamento jurídico sobre o qual irradiam seus efeitos. Por serem normas de elevado grau de abstração e generalidade, exigem uma aplicação influenciada por um elevado grau de subjetividade do intérprete.

A teoria moderna do Direito Público, já sob a ótica do marco filosófico do pós-positivismo que superou a dimensão puramente axiológica, ética, sem eficácia jurídica dos princípios para proclamar a sua normatividade, é capitaneada pelos estudos de Dworkin ${ }^{52}$ e pelos desenvolvimentos dados a sua concepção por Alexy. Tal teoria define os princípios como a norma jurídica mais importante do ordenamento jurídico ou como a "fonte primária de normatividade", nos dizeres de Bonavides. ${ }^{53}$

Essa segunda corrente doutrinária preconiza que as normas em geral enquadram-se em duas grandes categorias, quais sejam, os princípios e as regras. Superou-se a distinção do critério da generalidade (regras de conteúdo objetivo e princípios com maior teor de abstração) para uma distinção qualitativa, tendo os princípios, na lição de Canotilho, o papel de normas que impõem a otimização de um direito ou bem jurídico, da melhor forma possível, levando-se em conta as possibilidades e limitações fáticas e jurídicas. ${ }^{54}$

Dworkin, ao desenvolver premissas teóricas que avançassem para além do positivismo, utilizando-se da hermenêutica como ponto central, propôs a distinção entre princípios e regras jurídicas relativamente ao modo de aplicação e como são solucionadas as antinomias que surgem entre ambos. ${ }^{55}$

\footnotetext{
52 Ronald Dworkin procedeu a uma reviravolta antipositivista ao tratar os princípios como direito, proclamando que tanto os princípios quanto uma regra positivada podem impor uma obrigação legal.

${ }^{53}$ BONAVIDES, Paulo. Curso de direito constitucional. 9. ed. rev. atual. ampl. São Paulo: Malheiros, 2000. p. 175-176.

${ }^{54}$ CANOTILHO, Joaquim José Gomes. Direito constitucional e teoria da constituição. Coimbra: Livraria Almedina, 1998. p. 1086-1123.

${ }^{55}$ DWORKIN, Ronald. Levando os direitos a sério. São Paulo: Martins Fontes, 2002. p. 176.
} 
Para o autor, as regras estabelecem mandamentos definitivos e são aplicadas sob a lógica do tudo ou nada (all-or-nothing), ou seja, a hipótese de incidência da regra é preenchida e, por consequência, é considerada válida, ou ela não é preenchida e deve ser considerada inválida.

Já os princípios são tidos, para o citado autor, como fundamentos que devem levar o juiz a uma determinada decisão, que pode não ser a única conclusão, haja vista possuírem uma carga de peso ou importância inexistente nas regras. De tal modo, podem deixar de ser aplicados, ainda que ocorram as condições necessárias e suficientes, por prevalecer, no caso concreto, outro princípio de maior importância ou peso, sem que aquele princípio perca sua validade.

Para Dworkin, a estrutura principiológica, indeterminada em abstrato, mas determinável em concreto e aberta hermeneuticamente à construção intersubjetiva dos sentidos, reside na dimensão central do ordenamento jurídico composto fundamentalmente por princípios. ${ }^{56}$

A doutrina moderna consolidou o entendimento de que o sistema jurídico é composto por regras e princípios, ambos com status de norma jurídica, enfatizado em relação a esses últimos por Bobbio, quando afirma que:

[...] os princípios gerais são normas como todas as outras. E esta é também a tese sustentada por Crisafulli. Para sustentar que os princípios gerais são normas, os argumentos são dois, e ambos válidos: antes de mais nada, se são normas aquelas das quais os princípios gerais são extraídos, através de um procedimento de generalização sucessiva, não se vê por que não devam ser normas também eles: [...] Em segundo lugar, a função para qual são extraídos e empregados é a mesma cumprida por todas as normas, isto é, a função de regular um caso. E com que finalidade são extraídos em caso de lacuna? Para regular um comportamento não regulado: mas então

${ }^{56}$ DWORKIN, Ronald. Levando os direitos a sério. São Paulo: Martins Fontes, 2002. p. 176. 
servem ao mesmo escopo a que servem as normas expressas. E por que não deveriam ser normas? ${ }^{57}$

No campo do Direito Previdenciário, Martinez assevera que os princípios do Direito da Seguridade Social devem cumprir algumas funções, dentre elas, a "informativa", ou seja, de inspiração do criador da norma; a "construtivista" no sentido de indicar o caminho a ser perseguido no futuro, ante o seu aspecto de formulador da filosofia predominante numa determinada ordem jurídica; a "normativa", quando contidos no bojo de um comando normativo positivado assumem um caráter obrigatório e vinculativo; a "interpretativa", no sentido de auxiliar na solução e interpretação de normas obscuras, contraditórias ou em lacunas do direito; e, por fim, a "integrativa", enquanto instrumento de integração do ordenamento jurídico. ${ }^{58}$

O Direito Previdenciário, enquanto ramo autônomo do Direito, tem princípios próprios cujas nomenclaturas ainda não se apresentam uniformes, em razão da história recente dos estudos doutrinários específicos, precipuamente após o advento da Constituição Federal de 1988.

A sistematização da temática envolvendo os regimes geral e próprio, pela Constituinte de 1988, em Títulos distintos no corpo da Carta Constitucional, na visão de Briguet, Magadar Rosália Costa; Victorino, Maria Cristina Lopes e Miguel Horvath Junior (2007, p. 27), evidencia o intento de aproximar, cada vez mais, a configuração dos regimes previdenciários públicos, com a introdução de princípios do regime geral nos regimes próprios.

No contexto dos princípios genéricos da Seguridade Social, explicitamente referidos na Carta Constitucional, aplicáveis tanto ao regime geral quanto aos próprios de Previdência Social, podemos observar que o artigo 194 da Constituição Federal prescreve os objetivos que devem ser levados em conta pelo Poder Público na organização da Seguridade Social.

São considerados pela doutrina como verdadeiros princípios vetores da Seguridade Social, quais sejam: I - universalidade da cobertura e do atendimento; II - uniformidade e equivalência dos benefícios e serviços

${ }^{57}$ BOBBIO, Norberto. Teoria do ordenamento jurídico. 7. ed. Trad. Maria Celeste Cordeiro Leite dos Santos. Brasília: UnB, 1996. p. 158-159.

${ }^{58}$ MARTINEZ, Wladimir Novaes. Princípios de direito previdenciário. 4. ed. São Paulo: LTr, 2001. p. 9-11. 
às populações urbanas e rurais; III - seletividade e distributividade na prestação dos benefícios e serviços; irredutibilidade do valor dos benefícios; IV - equidade na forma de participação no custeio; $\mathrm{V}$ - diversidade da base de financiamento; VI - caráter democrático e descentralizado da administração, mediante gestão quadripartite, com participação dos trabalhadores, dos empregadores, dos aposentados e do governo nos órgãos colegiados.

\section{O CONCEITO DE UNIÃO ESTÁVEL NA ATUALIDADE}

Prosseguindo, para melhor compreensão da hipótese fática de concessão do benefício previdenciário de pensão por morte ao companheiro putativo do segurado falecido, é preciso ter em mente o conceito, nos dias atuais, do instituto da união estável.

A união livre entre homem e mulher caminhou, ao longo da história, paralelamente à entidade da família constituída pelo casamento. Nos dias atuais, já tratamos mais abertamente e com reconhecimento jurídico, da união livre entre pessoas do mesmo sexo.

A entidade familiar é um conceito mais sociológico do que jurídico, embora sempre tenha merecido a atenção de historiadores, sociólogos e juristas, haja vista que, enquanto fato social, sofreu, e ainda sofre, mudanças na sua conformação essencial operadas de acordo com a evolução da história mundial que, nos dizeres de Pereira (2004, p. 5), revelam-se imprescindíveis para a continuidade da sociedade e do Estado.

Do ponto de vista jurídico, a ideia de entidade familiar, no âmbito do ordenamento brasileiro, espelha-se no direito romano como padrão de organização familiar - constituída de pais e filhos unidos por intermédio do casamento - merecedora de proteção do Estado e capaz de gerar direitos e obrigações.

A estrutura familiar patriarcal e monogâmica sofreu transformações sociais que, na modernidade, impuseram a necessidade de reconhecimento dos inúmeros vínculos que não advêm do casamento.

Wald destaca que, por muito tempo, os tribunais foram vacilantes ao tratar do tema do companheirismo, ora negando ora reconhecendo efei- 
tos patrimoniais da união extramatrimonial, citando, com exemplo, acórdão do Supremo Tribunal Federal, segundo o qual "[...] a ordem jurídica ignora a existência do concubinato". 59

A Constituição Federal de 1988 trouxe novas conotações à figura tormentosa da união livre, ao prescrever no artigo 226, $\S 3^{\circ}$, que: "Para efeito de proteção do Estado, é reconhecida a união estável entre o homem e a mulher como entidade familiar, devendo a lei facilitar sua conversão em casamento."

O doutrinador Pereira explica a opção do legislador constituinte pela utilização da expressão "união estável” em substituição ao concubinato, posto que esse último "[...] é a indicação de um modo de vida ou um estado, a marca de um (pré)conceito que se vem formando ao longo do tempo. Por exemplo, nomear uma mulher de concubina é socialmente uma ofensa, é como se referisse à sua conduta moral e sexual de forma negativa". 60

O período que se estendeu da promulgação da Constituição $\mathrm{Fe}-$ deral de 1988 até a edição da Lei do Concubinato, no ano de 1994, nas palavras do doutrinador Leite, foi marcado pelo "[...] caos, porque, sem rumo e sem princípios coerentes, a matéria foi tratada de forma tão variável e contraditória que não se conseguia determinar a linha, ou o perfil de uma tendência nitidamente nacional". ${ }^{61}$

A primeira regulamentação da norma constitucional, com a promulgação da Lei 8.971/94 definiu como "companheiros" o homem e a mulher que mantinham união comprovada, por mais de cinco anos, ou com prole, na qualidade de solteiros, separados judicialmente, divorciados ou viúvos.

A Lei 9.278/96, dita "Lei dos Conviventes" por utilizar a expressão "conviventes" em substituição a "companheiros", alterou o conceito ao omitir os requisitos de natureza pessoal, tempo mínimo de convivência e existência de prole. Definia a entidade familiar, no seu artigo $1^{\circ}$, como a "convivência duradoura, pública e contínua, de um homem e de uma mulher, estabelecida com o objetivo de constituição de família".

\footnotetext{
${ }^{59}$ WALD, Arnoldo. Direito Civil: Direito de Família. 17. ed. São Paulo: Saraiva, 2009. p. 168.

${ }^{60}$ PEREIRA, Rodrigo da Cunha. Concubinato e união estável. 7. ed. rev. e atual. Belo Horizonte: Del Rey, 2004. p. 13.

${ }^{61}$ LEITE, Eduardo de Oliveira. Direito de família. São Paulo: RT, 2005. v. 5. p. 421.
} 
A união estável, enquanto relação familiar nascida fora do casamento, ganhou novos contornos dentro do ordenamento jurídico, com a edição do Código Civil de 2002 que fez significativas mudanças, no Livro de Direito de Família, estabelecendo em cinco artigos (1723 a 1727) os princípios diretores do instituto da união estável. No artigo 1723, o Código Civil disciplina que: "É reconhecida como entidade familiar a união estável entre o homem e a mulher, configurada na convivência pública, contínua e duradoura e estabelecida com o objetivo de constituição de família."

No campo da legislação previdenciária, a expressão companheira/companheiro foi a mais utilizada para designar os partícipes das relações extramatrimoniais.

Para prosseguirmos no presente estudo, ainda faz-se necessário adentrarmos, mesmo que brevemente, no conceito da união estável putativa, formulado a partir da teoria do casamento putativo ${ }^{62}$, cuja origem etimológica do termo putativo advém do latim putativus (imaginário), putare (crer, imaginar).

Dentre inúmeras definições doutrinárias, podemos citar o conceito de Rodrigues, para quem o casamento putativo "[...] é o casamento reputado ser o que não é. A lei, por meio de uma ficção e tendo em vista a boa-fé dos contraentes ou de um deles, vai atribuir ao casamento anulável, ou mesmo nulo, os efeitos do casamento válido,[...]". ${ }^{63}$

Trata-se de um regime de exceção dentro da teoria das nulidades do casamento perfeitamente aplicável ao instituto da união estável - equiparado à entidade familiar pelo Constituinte de 1988 -, para reconhecer-se efeitos pessoais, patrimoniais, em relação a terceiros e ao companheiro de boa-fé.

O instituto da união estável putativa é conceituado por Veloso (1997, p. 46) como sendo uma união paramatrimonial que, em razão da boa-fé de um ou ambos os companheiros, deve ser regida pelos mesmos princípios que orientam o casamento, nos termos seguintes:

[...] tratar-se-á de uma união estável putativa, que tem de gerar consequências patrimoniais à companheira,

\footnotetext{
${ }^{62} \mathrm{O}$ artigo 1561 do Código Civil disciplina que: "Embora anulável ou mesmo nulo, se contraído de boa-fé por ambos os cônjuges, o casamento, em relação a estes como aos filhos, produz todos os efeitos até o dia da sentença anulatória."

${ }^{63}$ RODRIGUES, Silvio. Direito Civil. 27. ed. São Paulo: Saraiva, 2002, v. 6. p. 111.
} 
sem prejuízo da esposa, é óbvio (...) a união estável é uma convivência qualificada, 'more uxorio', de caráter notório dotada de estabilidade, permanência, com um substrato moral relevante e o ânimo de permanecer juntos, de constituir família. Os partícipes vivem maritalmente, embora sem casamento. Conforme antes mencionamos, a união estável de um casal transmite a todos a aparência de um casamento ('marriage apparent, 'ménage de fait', como se diz na doutrina francesa). Trata-se, pois, de situação paraconjugal, paramatrimonial, estabelecendo comunidade de vida à qual se aplicam, até pela íntima semelhança, quase igualdade, os princípios do casamento. E nosso sistema, nossa civilização só admite o casamento monogâmico. Não iria transigir com uma 'união estável' poligâmica ou poliândrica. Mas pode acontecer de um dos parceiros estar de boafé, convicto que integra uma entidade familiar, com todos os requisitos que a lei estipula, sem saber que o outro mantém diversa união ou, até, outras uniões. Podemos falar aqui, igualmente, com relação ao convivente de boa-fé, numa união estável 'putativa', para efeito de gerar consequências para este parceiro inocente.

Em verdade, na união estável putativa, a companheira ignora a existência de esposa ou de outras companheiras preexistentes e, por consequência, desconhece os reflexos de tal união. A recíproca para o companheiro que, de boa-fé, mantinha união com segurada casada e não separada de fato, também é verdadeira.

\section{A PENSÃO POR MORTE DEVIDA AO COMPANHEIRO OU COMPANHEIRA}

Na seara dos beneficiários dos regimes públicos de Previdência Social, é preciso considerar que, conquanto previstos vários regimes previdenciários, a Constituição Federal prescreveu no artigo 40, §12, a unidade de proteção previdenciária, norteada pelos princípios da universali- 
dade de cobertura e de atendimento, uniformidade e equivalência de cobertura e atendimento entre as populações urbanas e rurais, com vistas a reduzir as desigualdades de prestações entre os regimes.

Não obstante o sistema dos regimes próprios não seja de âmbito nacional, tal como ocorre com o regime geral, existem regras gerais prescritas na Constituição Federal, de observância obrigatória pelos entes públicos.

O presente estudo limitar-se-á à análise do benefício de pensão por morte, destinado exclusivamente aos dependentes do segurado, em especial, ao companheiro do segurado falecido, na hipótese de união estável putativa.

Na esteira da lição de Borges, a pensão por morte constitui-se num clássico benefício previdenciário, tendo no regime funcional precedido à própria previsão de aposentadoria, com importante repercussão social: "Isso porque seu evento gerador - morte do segurado - possui grande apelo emocional e sua finalidade - repor a renda que o segurado propiciava à manutenção de seus dependentes - grande repercussão econômica e social". ${ }^{6}$

No âmbito do regime geral de Previdência Social, o benefício previdenciário da pensão por morte está disciplinado nos artigos 74 a 79 da Lei n. 8.213/91. Constitui-se num benefício de prestação continuada, pago ao conjunto de dependentes do segurado falecido, aposentado ou não, a contar da data: a) do óbito, quando requerido até trinta dias depois deste; b) do requerimento, quando requerido após trinta dias; c) da decisão judicial que reconhecer a morte presumida.

A Lei de Benefícios Previdenciários arrola no artigo 16, inciso I, os seguintes dependentes do segurado: cônjuge, companheira, companheiro e o filho não emancipado, de qualquer condição, menor de 21 anos ou inválido.

No que diz respeito aos regimes próprios de Previdência Social, com a promulgação da Emenda Constitucional n ${ }^{\circ}$ 20/98, o instituto da pensão por morte sofreu um processo de constitucionalização, com a obrigatoriedade de observância dos requisitos e critérios fixados para a concessão do mesmo benefício pelo regime geral de Previdência Social.

${ }^{64}$ BORGES, Mauro Ribeiro. Previdência funcional. 1. ed., 2. Tiragem. Curitiba: Juriá, 2007. p. 167. 
$\mathrm{O}$ artigo $5^{\circ}$ da Lei $9.717 / 98$ dispõe que os regimes próprios de Previdência Social não poderão conceder benefícios distintos daqueles previstos no regime geral. Elencou, ainda, como beneficiários da pensão por morte os mesmos dependentes arrolados no artigo 16 da Lei 8.213/91.

A norma previdenciária estabelece que a dependência financeira daqueles que figuram na primeira classe é presumida e, portanto, apresenta vínculo mais abrangente do que aqueles resultantes dos laços da família civil. Nos dizeres de Coimbra (1998, p. 97), tal critério é adotado em razão da finalidade da proteção social. Disciplina, ainda, que a existência de dependentes de qualquer das classes exclui do direito à percepção das prestações os dependentes das classes seguintes.

No que diz respeito aos companheiros/companheiras dependentes do segurado falecido, a aplicação da legislação previdenciária, pelo órgão gestor do regime geral de Previdência Social, ao longo do tempo, vem reconhecendo o caráter subjetivo do vínculo de companheiro/companheira. Tem-se assegurado a concessão de benefício previdenciário, na qualidade de dependente do segurado, ao companheiro que manteve união estável com o segurado falecido, ainda que esse fosse casado, desde que desconhecesse tal impedimento e comprovasse dependência econômica e a relação de união estável.

Nesta esteira, Pessoa destaca que:

Há que se antever situações nas quais o concubinato pode ser puro somente para uma das partes, aquela que se encontra de boa-fé, admitindo-se, em seu favor, a proteção conferida pela lei, uma vez encontrados nessa união putativa os elementos essenciais e atendidos os fatores de eficácia próprios da generalidade dos casos. ${ }^{65}$

Também Viana, reconhecendo a possibilidade de existir união estável putativa, elenca como efeitos civis em favor do companheiro de boa-fé, dentre eles, o direito à meação do patrimônio havido na constância

\footnotetext{
${ }^{65}$ PESSOA, Claudia Grieco Tabosa. Efeitos patrimoniais do concubinato. São Paulo: Saraiva, 1997. p. 46.
} 
da união estável e o de ser herdeiro, em não havendo descendente ou ascendente. ${ }^{66}$

No âmbito do regime geral de Previdência Social, a concorrência do direito da companheira em relação à esposa legítima, no recebimento do benefício previdenciário de pensão por morte, é analisada pela Autarquia Previdenciária diante de cada caso concreto, "predominando o espírito da lei sobre a forma, devidamente adequado ao fato social sobre o qual incide", nas palavras de Pires. ${ }^{67}$

No entanto, o mesmo não ocorre nos regimes próprios de Previdência Social onde se verifica uma predominância do não reconhecimento do direito da companheira putativa no recebimento de pensão por morte de segurado casado.

Não é raro, no nosso dia-a-dia, nos depararmos com a situação da dupla vida conjugal, na qual um homem/mulher consegue administrar uma família, legalmente constituída, com outro relacionamento sério e duradouro, do qual também é responsável pela administração e sustento dos entes familiares.

Os Tribunais Superiores pátrios firmaram entendimento jurisprudencial $^{68}$, ainda não unânime no Superior Tribunal de Justiça, acerca do não reconhecimento do direito de perceber pensão por morte, pelo companheiro do segurado falecido, ante a constatação de concubinato adulterino, ainda que putativo.

O Ministro Cézar Peluso no julgamento do RE 491.039/RJ, com fundamento no artigo 226 da Constituição Federal e Lei nº: 9.278/96, não

\footnotetext{
${ }^{66}$ VIANA, Marco Aurélio S. Da união estável. São Paulo: Saraiva, 1999. p. 91.

${ }^{67}$ PIRES, Maria da Graça M. S. Soromenho. O concubinato no direito brasileiro. Rio de Janeiro: Forense, 1998. p. 71.

${ }^{68}$ Em relação ao STF podemos citar: RE 590.779, Rel. Min. Marco Aurélio, $1{ }^{\text {a }}$ Turma, DJE de 27/03/2009, disponível em <http://www.stf.jus.br/portal/processo/ verProcessoAndamento.asp?incidente $=2630734>$. Acesso em 10 de abril de 2014; RE 397.762, Rel. Min. Marco Aurélio, $1^{\text {a }}$ Turma, DJE de 12/09/2008, disponível em <http://www.stf.jus.br/portal/processo/verProcessoAndamento.asp?incidente=2150768>. Acesso em 10 de abril de 2014; MS 27.871-MC, Rel. Min. Ellen Gracie, DJE de 17/03/2009, disponível em <http://www.stf.jus.br/portal/processo/verProcessoAndamento.asp?incidente=2652157> . Acesso em 10 de abril de 2014; RE 491.039, Rel. Min. Cezar Peluso, DJE de 05/08/2009, disponível em http://www.stf.jus.br/portal/processo/verProcessoAndamento.asp?incidente $=2382680>$. Acesso em 10 de abril de 2014 .
} 
reconheceu o direito de a companheira perceber pensão por morte de servidor público em detrimento da esposa legítima. O referido recurso foi interposto contra acórdão cujo excerto da emenda dispõe que:

[...] A norma constitucional prevê que a lei deverá facilitar a conversão da união estável em casamento, o que, obviamente, é impossível se um dos conviventes for casado. 4 - Não se pode admitir que uma Constituição que traduz em capítulo especial a preocupação do Estado quanto à família, trazendo-a sob o seu manto protetor, desejasse debilitá-la e permitir que uniões adulterinas fossem reconhecidas como uniões estáveis, hipótese em que teríamos bigamia de direito (TJERJ - $\mathrm{AC} \mathrm{n}^{\circ}$ 1999.001.12292). Em uma sociedade monogâmica, o ordenamento jurídico não protege o concubinato adulterino, relação paralela ao matrimônio. A caracterização da união estável depende, inicialmente, da falta de impedimento de ambos os companheiros em estabelecer a relação. ${ }^{69}$

No âmbito do Superior Tribunal de Justiça a matéria não está pacificada. As Terceira, Quarta e Sexta Turmas ${ }^{70}$, na esteira do entendimento

$69 \quad$ Disponível em: <www.stf.jus.br/portal/processo/ver ProcessoAndamento.asp?incidente $=2382680>$. Acesso em 7 de abril de 2014. p. 01.

$70 \quad$ AgRg no Ag 683.975/RS, $3^{\text {a }}$ Turma, Ministra Relatora Vasco Della Giustina, julgado em 18/08/2009, disponível em https://ww2.stj.jus.br/processo/revista/documento/mediado/?componente=MON\&sequencial $=3594471 \&$ num_registro $=200400718421 \&$ data $=20071212 \&$ formato $=P D F>$. Acesso em 10 de abril de 2014; Resp 789.293/RJ, $3^{\text {a }}$ Turma, Rel. Min. Carlos Alberto Menzes Direito, DJ de 20/03/2006, disponível em <https://ww2.stj.jus.br/processo $/$ revista/documento/mediado/?componente=ATC\&sequencial=2269460\&num_regis-

tro $=200501653798 \&$ data $=20060320 \&$ tipo $=5 \&$ formato $=P D F>$. Acesso em 10 de abril de 2014; AgRg no Ag 683.975/RS, $3^{\text {a }}$ Turma, Ministra Relatora Vasco Della Giustina, julgado em 18/08/2009, disponível em <https://ww2.stj.jus.br/processo/revista/documento/ mediado/?componente=ATC\&sequencial $=5900102 \&$ num_regis-

tro $=200500907357 \&$ data $=20090902 \&$ tipo $=5 \&$ formato=PDF.$>$ Acesso em 10 de abril de 2014; Resp 1.104.316/RS, $6^{a}$ Turma, Rel. Min. Maria Thereza de Assis Moura, DJE de 18/05/2009, disponível em <https://ww2.stj.jus.br/processo/revista $/$ documento/mediado/?componente=ATC\&sequencial=5152254\&num_registro $=200802385477 \&$ data $=20090518 \&$ tipo $=5 \&$ formato $=P D F>$. Acesso em 10 de abril de 2014; Resp 674.176/PE, 6 a Turma, Rel. Min. Nilson Naves, DJE de 31/08/2009, disponível 
sufragado pela Corte Constitucional, firmaram posicionamento de que a existência de impedimento para o matrimônio, por parte de um dos companheiros, impede a constituição da união estável, não gerando efeitos jurídicos para a concubina, inclusive para fins previdenciários.

No julgamento do Recurso Especial 1.114.490/RS, interposto contra acórdão do Tribunal Regional Federal da $4^{\mathrm{a}}$ Região que entendeu que o estado civil de casado do falecido não impedia a concessão de benefício de pensão por morte à companheira, em conjunto com a esposa, com quem havia convivido por quase 22 anos, o Ministro Jorge Mussi, no voto de relatoria proferido, aduziu que:

A hipótese de concomitância, portanto, em que relação matrimonial e de concubinato ocorrem simultaneamente, como restou incontroverso no caso em tela, por não se amoldar ao modelo estabelecido pela legislação previdenciária e tampouco pela Constituição Federal, não são capazes de ensejar união estável.

Afigura-se inviável, assim, reconhecer à recorrida o direito à percepção da pensão por morte em concurso com a viúva, haja vista que o de cujus, à época do óbito, permanecia casado com a recorrente. ${ }^{71}$

No entanto, a Quinta Turma do Superior Tribunal de Justiça ${ }^{72}$, em mais de uma oportunidade, assentou a possibilidade de a companheira

em

https://ww2.stj.jus.br/processo/revista/documento/mediado/?componente=ATC\&sequencial $=6008309 \&$ num_registro $=200400998572 \&$ data $=20090831 \&$ tipo $=5 \&$ formato $=P D F>$. Acesso em 10 de abril de 2014; $\operatorname{Resp~684.407/RS,~} 4^{\mathrm{a}}$ Turma, Rel. Min. Jorge Scartezzini, julgado em 03/05/2005, disponível em <https://ww2.stj.jus.br/processo/ revista/documento/mediado/?componente $=$ ATC\&sequencial=1774670\&num_regis-

tro $=200401223595 \&$ data $=20050627 \&$ tipo $=5 \&$ formato $=P D F>$. Acesso em 10 de abril de 2014.

$71 \quad$ Disponível em <https://ww2.stj.jus.br/processo/revista $/$ documento/mediado/?componente $=$ ATC\&sequencial $=5746756 \&$ num_regis-

tro $=200900786830 \&$ data $=20100201 \&$ tipo $=5 \&$ formato $=P D F>$. Acesso em 7 de abril de 2014.

${ }^{72}$ Resp 856.757/SC, Rel. Min. Arnaldo Esteves Limas, DJ de 02/06/2008, disponível em $<$ https://ww2.stj.jus.br/processo/revista/documento/mediado/?componente=MON\&sequencial $=5251605 \&$ num_registro $=200601182240 \&$ data $=20090526 \&$ tipo $=0 \&$ for mato=PDF $>$. Acesso em 10 de abril de 2014; Resp 628.140/RS, Rel. Min. Laurita Vaz, DJ 
perceber, em rateio com a esposa legítima, a pensão por morte do segurado falecido.

O Ministro José Arnaldo da Fonseca, no voto relator do julgamento do Recurso Especial 742.685/RJ, após consignar que "o falecido era casado com a recorrente e dela não se separou, mas, concomitantemente, manteve relação amorosa com a recorrida, durante 30 anos, instituiu-a beneficiária da previdência social, abriu com ela conta conjunta em estabelecimento bancário.", proferiu voto nos termos seguintes dos excertos abaixo transcritos:

Ante uma situação de fato dessa ordem, que perdurou por 3 (três) décadas, de que se extrai o reconhecimento de efetiva affectio societatis, poderia o magistrado prostrar-se inerte, indiferente, apegado ao hermetismo dos textos legais, deslembrado do princípio de que, na aplicação da lei, há de se atender aos fins sociais? ${ }^{73}$

Em suma, o entendimento jurisprudencial majoritário nos Tribunais Superiores, em relação ao tema em estudo, resulta da conjugação literal do artigo 226, § $3^{\circ}$ da Constituição Federal, artigo $1^{\circ}$ da Lei 9.278/1996 e artigos 1521, inciso VI do Código Civil e 235 do Código Penal.

No entanto, o não reconhecimento dos efeitos jurídicos decorrentes da união estável putativa em favor da companheira de boa-fé, não se coaduna com o espírito de proteção previdenciária do beneficiário em situação de risco social, qual seja a ausência do provedor familiar.

de 17/09/2007, disponível em <https://ww2.stj.jus.br/processo/revista/ documento/mediado/?componente=ATC\&sequencial=3699298\&num_regis-

tro $=200302223423 \&$ data=20080324\&tipo=5\&formato=PDF $>$. Acesso em 10 de abril de 2014; Resp 742.685/RJ, 5 a Turma, Ministro Relator José Arnaldo da Fonseca, julgado em 04/08/2005, disponível em https://ww2.stj.jus.br/processo/revista/documento/mediado/?componente $=$ ATC $\&$ sequencial $=2081984 \&$ num_regis-

tro $=200500622011 \&$ data $=20051121 \&$ tipo $=5 \&$ formato=PDF $>$. Acesso em 10 de abril de 2014.

73 Disponível em: <https://ww2.stj.jus.br/processo/revista/documento/ mediado/?componente $=$ ATC\&sequencial $=2081984 \&$ num_regis-

tro $=200500622011 \&$ data $=20051121 \&$ tipo $=5 \&$ formato $=P D F>$. Acesso em 7 de abril de 2014. 
Consoante o registro de Borges (2007, p. 191), o ramo do Direito Previdenciário, antes mesmo da Constituição Federal de 1988 e do ordenamento positivado do Direito de Família, “[...] mormente pelo desforço jurisprudencial [...]", foi o primeiro ramo do Direito a reconhecer direitos às companheiras, na qualidade de dependentes do segurado, em especial, o direito a pensão por morte.

Desse modo, imprescindível a (re)construção de uma única resposta correta, nos casos específicos de união estável putativa, que leve em consideração as circunstâncias especiais que envolvem tal situação, em especial a boa-fé da companheira putativa. Sobre esse tema é que trata o capítulo seguinte.

\section{A (RE)CONSTRUÇÃO DE UMA SÓ RESPOSTA NOS CASOS DE UNIÃO ESTÁVEL PUTATIVA}

O entendimento jurisprudencial de nossos Tribunais Superiores, acerca do não reconhecimento do direito do companheiro putativo perceber pensão por morte, com fundamento na conjugação literal do disposto no artigo 226, $\S 3^{\circ}$ da Constituição Federal, artigo $1^{\circ}$ da Lei 9.278/1996 e artigos 1521, inciso VI do Código Civil e 235 do Código Penal, nos faz refletir sobre a necessidade de se buscar uma resposta que melhor atenda aos princípios da equidade e da justiça social no caso concreto, essa última entendida, na lição de José Fernando de Castro Farias, como parâmetro da experiência jurídica que tem como referência " [...]valores éticos, morais e sociais que não são criados por uma transcendência, nem procurados numa instância exterior, mas sim neste mundo onde vivemos, inscrevendo-se numa lógica de imanência dos valores morais e sociais". ${ }^{74}$

Muito se tem discutido na doutrina contemporânea sobre o papel do intérprete e seus limites, a integração subjetiva dos princípios, normas abertas, conceitos indeterminados, demonstração racional das escolhas e decisões do intérprete.

\footnotetext{
${ }^{74}$ FARIAS, José Fernando de Castro. A origem do direito de solidariedade. Rio de Janeiro: Renovar, 1998. p. 279.
} 
É de fundamental importância, no contexto do Estado Democrático de Direito ${ }^{75}$, o reconhecimento da necessidade de o aplicador do Direito manter uma postura interpretativa que alcance efetividade aos direitos assegurados na Constituição Federal. Deverá, para tanto, na visão de Rocha, estar sempre aberto ao novo, com vistas a possibilitar a "[...] tomada de decisões sempre diferentes, inserindo a sociedade no paradoxo comunicativo da invenção". ${ }^{76}$

Nos casos concretos de proteção previdenciária da união estável putativa, tem-se verificado, no âmbito dos Tribunais Superiores pátrios, a aplicação literal das normas jurídicas, levando em conta meramente o aspecto objetivo dos requisitos legais para o reconhecimento do direito de obtenção ao benefício previdenciário de pensão por morte.

Tencionamos demonstrar a relevância da (re)construção de uma só resposta correta nos casos de proteção previdenciária da união estável putativa, não no sentido de que seja possível apenas uma única resposta para o caso concreto, mas, sim, que existe um horizonte de possibilidades de construção de uma só resposta para cada caso concreto que se modifica com as próprias transformações sociais ao longo do tempo.

Para tanto, nos valemos da teoria elaborada pelo jus-filósofo Dworkin, fundada num sistema de direitos baseado na ideia de integridade do direito, posto que "[...] todos foram criados por um único autor - a comunidade personificada -, expressando uma concepção coerente de justiça e equidade." que implica na construção de uma interpretação que leve em conta toda a estrutura principiológica da Constituição, num todo coerente, e da nossa história constitucional. ${ }^{77}$

Crítico das escolas positivistas (manifestação da teoria jurídica liberal tradicional) e utilitaristas (manifestação da filosofia política liberal),

\footnotetext{
75 O paradigma do Estado Democrático de Direito, na visão de Jürgen Habermas (1997), exige o reconhecimento e o respeito das diferentes formas de vida, das diversidades de opiniões e do próprio direito à divergência e um direito que interprete a lei sem estabelecer a primazia dos valores de certo grupo sobre os demais membros da comunidade. O pluralismo político está assegurado em nossa Carta Magna, no seu artigo $1^{\circ}$, quando prescreve que tantos os valores sociais quanto os políticos constituem-se, igualmente, princípios fundamentais da República.

${ }^{76}$ ROCHA, Leonel Severo. Epistemologia jurídica e democracia. São Leopoldo: Unisinos, 1998. p. 100.

${ }^{77}$ DWORKIN, Ronald. O império do direito. 2. ed. São Paulo: Martins Fontes, 2007. p. 271-272.
} 
Dworkin considera que uma teoria geral do Direito não pode separar o Direito como ciência descritiva da moral e da política jurídica. Propõe uma conexão entre o Direito, a moral e a política que reflete na atividade de interpretação e consideração do conteúdo material do Direito. Para o autor, as normas positivas encontram seu fundamento de validade nos princípios que, por sua vez, são informados por valores morais.

Para Dworkin, o Direito representa uma atividade interpretativa em contínuo desenvolvimento, que se mostrará sempre melhor na medida em que o intérprete conseguir expressar o significado do direito em sua integridade e não apenas o de uma norma específica, pois o significado de cada norma deve ser coerente com os princípios que integram todo o ordenamento. ${ }^{78}$

Concebendo o ordenamento jurídico composto fundamentalmente por princípios, cujo conteúdo material (dimensão do seu peso ou importância) é o que determina quando deve ser aplicado em uma ou outra situação, Dworkin ${ }^{79}$ apresenta a tese de que o juiz deve buscar um único princípio jurídico ${ }^{80}$ adequado ao caso concreto - aquele que tenha maior força de convencimento -, promovendo uma justificação racional do princípio eleito por meio de um discurso de adequação que se revela também interpretação jurídica e não uma mera subsunção de fatos concretos a normas postas.

Propõe, então, um novo modelo para a função judicial baseado na resposta correta, sempre encontrada pelo juiz no direito preestabelecido. O juiz não tem discricionariedade e nem poder político, mas tão-somente o dever de descobrir o direito das partes e aplicar a norma correspondente de forma interpretada. A resposta correta corresponde à teoria que melhor justificaria os conteúdos jurídicos existentes e que se aplica ao caso concreto.

O aplicador do Direito, concebendo-o em sua integridade ${ }^{81}$, imbuído do espírito de levar a sério os direitos envolvidos e tratando a questão

\footnotetext{
${ }^{78}$ DWORKIN, Ronald. O império do direito. 2. ed. São Paulo: Martins Fontes, 2007. p. 217.

${ }^{79}$ Idem. p. 42.

${ }^{80}$ Para Ronald Dworki os princípios devem ser observados por uma "exigência de justiça ou equidade ou alguma outra dimensão da moralidade". DWORKIN, Ronald. Levando os direitos a sério. São Paulo: Martins Fontes, 2002. .p. 36.

81 "A integridade expande e aprofunda o papel que os cidadãos podem desempenhar individualmente para desenvolver as normas públicas de sua comunidade, pois exige que tratem
} 
como um caso difícil ou hard cases, na visão de Vieira, deverá interpretar as normas do ordenamento jurídico com vistas à manutenção de uma coerência interna que lhe confira a unidade para, ao final, demonstrar que a decisão no caso concreto é a melhor realização possível dos comandos constitucionais. $^{82}$

Dworkin assevera que, mesmo quando nenhuma regra regula o caso, uma das partes pode, ainda assim, ter o direito de ganhar a causa e o "juiz continua tendo o dever, mesmo nos casos difíceis, de descobrir quais são os direitos das partes". ${ }^{83}$

A solução, então, deve ser buscada na "dimensão da adequação", com a eleição, dentro do ordenamento jurídico, daquele princípio abstrato que, diante das especificidades da situação posta, melhor se adeque ao caso concreto, sem que a legitimidade ou validade dos demais princípios afastados sejam afetadas, mantendo a coerência e a integridade de todo o sistema.

Para Dworkin, a "questão de adequação" 84 ou o "teste de adequação" 85 , consiste em verificar qual a norma ou princípio diretamente pertinente ao caso concreto e, em seguida, sua adequação às normas gerais que, em última instância, deverão ser adequadas às próprias normas constitucionais.

Para lidar produtivamente com a hermenêutica, o autor adota o modelo da interpretação construtiva do Direito, que funciona do ponto de vista interno dos próprios intérpretes, posto que "uma teoria da interpretação é uma interpretação da prática dominante de usar conceitos interpretativos". 86

Nas palavras de Dworkin:

as relações entre si mesmos como se estas fossem regidas de modo característico, e não espasmódico, por essas normas. [...] A integridade infunde às circunstâncias públicas e privadas o espírito de uma e de outra, interpenetrando-as para o benefício de ambas.". DWORKIN, Ronald. O império do direito. 2. ed. São Paulo: Martins Fontes, 2007. p. 230.

${ }^{82}$ VIEIRA, Oscar Vilhena. A constituição e sua reserva de justiça (um ensaio sobre os limites materiais ao poder de reforma). São Paulo: Malheiros, 1999. p. 198.

${ }^{83}$ DWORKIN, Ronald. Levando os direitos a sério. São Paulo: Martins Fontes, 2002.

.p. 127.

${ }^{84}$ DWORKIN, Ronald. O império do direito. 2. ed. São Paulo: Martins Fontes, 2007. p. 306.

${ }^{85}$ Idem. p. 311.

${ }^{86}$ DWORKIN, Ronald. O império do direito. 2. ed. São Paulo: Martins Fontes, 2007. p. 60 . 
É uma atitude contestadora que torna todo cidadão responsável por imaginar quais são os compromissos públicos de sua sociedade com os princípios, e o que tais compromissos exigem em cada nova circunstância. O caráter contestador do direito é confirmado, assim como é reconhecido o papel criativo das decisões privadas, pela retrospectiva da natureza judiciosa das decisões tomadas pelos tribunais, e também pelo pressuposto regulador de que, ainda que os juízes devam sempre ter a última palavra, sua palavra não será a melhor por essa razão. ${ }^{87}$

A interpretação construtiva, sempre restrita pelos limites impostos por um preceito geral e abstrato, buscará uma resposta que contemple as expectativas de produção de justiça no caso concreto e, ao mesmo tempo, as exigências de abstração e generalidade das normas jurídicas impostas pela Constituição.

Para tanto, o juiz deverá tratar o caso concreto como um caso difícil no sentido de tomar conhecimento de todos os argumentos presentes na demanda e tratar o processo como um texto a ser interpretado da melhor forma possível. Também as regras, assim como os princípios, precisam ser interpretadas e contextualizadas num sentido coerente com as demais normas do ordenamento, para que mantenha a integridade do direito como um todo.

É preciso que o intérprete do Direito, diante do caso concreto de união estável putativa, busque o significado presente da norma ${ }^{88}$ a partir de uma interpretação construtiva que revele a melhor compreensão possível do ordenamento jurídico e com efetivo conhecimento da atual realidade social, a fim de promover transformações que gerem a justiça e equidade no caso concreto, no bojo do devido processo legal.

\footnotetext{
${ }^{87}$ Idem. p. 492.

${ }^{88}$ Maria Lúcia Luz Leiria nos ensina que em relação a aplicação dos textos previdenciários: "[...] a compreensão do presente, da atualidade que deve ser conferida ao texto a ser aplicado, a ser entendido, deve passar por uma presença do intérprete, por uma valoração do pretendido direito frente aos objetivos e princípios constitucionais.". LEIRIA, Maria Lúcia Luz. Direito previdenciário e estado democrático de direito: uma (re)discussão à luz da hermenêutica. Porto Alegre: Livraria do Advogado, 2001. p. 43.
} 
Não podemos supor que sempre haverá objetividade absoluta nas decisões judiciais, pois, nas palavras de Dworkin, "[...] juristas e juízes sensatos irão divergir freqüentemente sobre os direitos jurídicos, assim como os cidadãos e os homens de Estado divergem sobre direitos políti$\cos " .89$

No entanto, a segurança jurídica no caso concreto será alcançada sempre que se demonstrar que se está a interpretar o caso concreto, sob o foco da luz do melhor direito, levando-se em conta os princípios orientadores de todo o ordenamento, em especial a Constituição Federal, e não apenas de um fragmento da norma.

Em outros termos, na lição de Oliveira:

O princípio da segurança jurídica requer decisões que podem ser consistentemente tomadas no quadro do Direito vigente e a pretensão de legitimidade da ordem jurídico-democrática requer decisões consistentes não apenas com o tratamento anterior de casos análogos e com o sistema de normas vigente, mas pressupõe igualmente que sejam racionalmente fundadas nos casos concretos, de tal modo que os cidadãos possam aceitálas como decisões racionais..$^{90}$

Com efeito, as causas que envolvem o Direito Previdenciário tratam de direito social assegurado na Constituição Federal que está intimamente relacionado com a sobrevivência e dignidade do beneficiário, seja ele segurado ou dependente.

O dever de proteção do Estado àqueles que efetivamente necessitam, por se encontram em um das situações de risco social, impõe que o aplicador do direito busque uma interpretação criativa que seja capaz de integrar ao caso concreto o princípio constitucional que assegure a maior efetividade do direito social prescrito na Constituição Federal, a fim de promover a proteção previdenciária ao companheiro putativo, de boa-fé e dependente econonicamente do segurado falecido.

O Ministro Carlos Ayres Brito, no voto-vista proferido no Recurso Extraordinário 397.762-8/BA, manifestou-se nos termos seguintes:

\footnotetext{
${ }^{89}$ DWORKIN, Ronald. Levando os direitos a sério. São Paulo: Martins Fontes, 2002. .p. 127-128.

${ }^{90}$ OLIVEIRA, Marcelo Andrade Cattoni de Oliveira. Crise e desafios da constituição: perspectivas críticas da teoria e práticas constitucionais brasileiras. In: SAMPAIO, José Adércio Leite (Coord). Jurisdição constitucional e direitos fundamentais. Belo Horizonte: Editora Del Rey, 2003. p. 524.
} 
Com efeito, à luz do Direito Constitucional brasileiro o que importa é a formação em si de um novo e duradouro núcleo doméstico. A concreta disposição do casal para construir um lar com um subjetivo ânimo de permanência que o tempo objetivamente confirma. Isto é família, pouco importando se um dos parceiros mantém uma concomitante relação sentimental a-dois. ${ }^{91}$

O doutrinador Borges sustenta que a supremacia do formalismo e da definição do Direito de Família contraria o fundamento primordial do Direito Previdenciário que é oferecer cobertura aos reais dependentes do segurado. ${ }^{92}$

A negativa de proteção previdenciária à companheira ${ }^{93}$, em situação de união estável putativa caracterizada, comumente, num relacionamento mantido por anos, às vezes décadas, com a geração de prole e a manutenção e proteção da família constituída a cargo do segurado, não se coaduna com o ideal democrático de concretização dos direitos fundamentais, no qual o Direito Previdenciário está inserido ${ }^{94}$ (artigo $6^{\circ}$ da Constituição Federal).

$91 \quad$ Disponível em: $\quad<$ http://redir.stf.jus.br/paginadorpub/paginador. jsp?docTP=AC\&docID=547259>. Acesso em 7 de abril de 2014. p. 629.

92 BORGES, Mauro Ribeiro. Previdência funcional. 1. ed., 2. Tiragem. Curitiba: Juriá, 2007. p. 124.

${ }^{93}$ Carlos Eduardo Pianovski destaca que "[...] não cabe ao Estado realizar um juízo prévio e geral de reprovabilidade contra formações conjugais plurais não constituídas sob sua égide, e que se constroem no âmbito dos fatos". PIANOVSKI, Carlos Eduardo. Famílias simultâneas e monogamia em família e dignidade humana. In: CONGRESSO BRASILEIRO DE DIREITO DA FAMÍlIA, 5, 2006, São Paulo. Anais do V Congresso Brasileiro de Direito de Família. São Paulo: IOB Thomson, 2006. p. 198.

${ }^{94}$ Alguns doutrinadores não vislumbram o caráter fundamental da Previdência Social, dentre eles podemos citar Ana Paula de Barcellos para quem: "[...] a previdência social não realiza de forma incondicional a assistência aos desamparados e, a fortiori, o princípio da dignidade da pessoa humana, já que, embora a filiação à previdência seja obrigatória (art. 201, caput), os benefícios dependerão sempre de comprovar-se a contribuição para o sistema". Ao que Marcelo Leonardo Tavares discorda, haja vista os "[...] diversos mecanismos de proteção existentes no sistema que independem da estrita contribuição e pelo caráter universal do modelo do Regime Geral brasileiro." BARCELLOS, Ana Paula de. A eficácia jurídica dos princípios constitucionais - O princípio da dignidade da pessoa humana. Rio 
A Constituição Federal de 1988, ao tratar da Previdência Social, consolidou princípios básicos fundamentadores do Estado Social e Democrático de Direito, em especial a dignidade da pessoa humana, alçando-a a um direito fundamental.

A dignidade da pessoa humana, enquanto princípio fundamentador dos direitos sociais prestacionais mínimos, cujo conteúdo material está delineado no artigo $6^{\circ}$ da Constituição Federal, incorporou-os à concepção material de direitos fundamentais, na visão de Tavares (2003, p. 158-159), vinculando-os a todos os fundamentos do Estado (artigo $1^{\circ}$ ) e aos objetivos de construção de uma sociedade livre, justa e solidária, à erradicação da pobreza e da marginalização e à redução das desigualdades sociais e regionais.

Desse modo, os direitos fundamentais sociais de cunho prestacional encontram-se, nas palavras de Sarlet " [...] a serviço da igualdade e da liberdade material, objetivando, em última análise, a proteção da pessoa contra as necessidades de ordem material e a garantia de uma existência com dignidade". 95

Não podemos nos esquecer que o direito social à proteção previdenciária, levado a efeito com a concessão do benefício de pensão por morte, está íntima e indissociavelmente vinculado ao princípio da dignidade humana, uma vez que reside na prestação contínua e periódica da pensão por morte ao companheiro putativo, ao lado do cônjuge legítimo, a garantia material mínima de uma vida digna, ante o infortúnio da ausência do provedor da família.

Para promover a mediação do direito de perceber pensão por morte do cônjuge legítimo ao lado do companheiro putativo, de acordo com a concretude e a singularidade de cada caso posto à apreciação do Poder Judiciário, é preciso interpretar o princípio da dignidade da pessoa humana, no conjunto de princípios abstratamente considerados, de modo a se conformar uma unidade coerente e íntegra com todo o restante do orde-

de Janeiro: Renovar, 2002. p. 189. TAVARES, Marcelo Leonardo. Previdência e assistência social. Legitimação e fundamentação constitucional brasileira. Rio de Janeiro: Lúmen Júris, 2003. p. 235.

95 SARLET, Ingo Wolfgang Sarlet. O direito fundamental à moradia na Constituição: algumas anotações a respeito de seu contexto, conteúdo e possível eficácia. In: SAMPAIO, José Adércio Leite (Coord). Jurisdição constitucional e direitos fundamentais. Belo Horizonte: Editora Del Rey, 2003. p. 430. 
namento pátrio, em especial as regras constitucionais e legais que disciplinam o instituto da união estável, para a promoção da equidade e justiça social.

Não podemos simplesmente fechar os olhos para a existência de famílias paralelas e ignorar a realidade social, deixando de amparar um integrante familiar em situação de risco social, sob o fundamento de que tal realidade não gera efeitos jurídicos. Ao aplicador do Direito incumbe analisar situações, muitas vezes consideradas imorais pela sociedade, de forma imparcial, desprovida de preconceito, com equidade e retidão para promover justiça e segurança jurídica em casos especiais como o da união estável putativa, a fim de "estabelecer igualitarismos, porquanto o desenvolvimento social depende de papéis e funções desiguais, diferentes, cada um com seu tratamento jurídico, permitindo a todos acesso social, na medida de suas competências", na visão de Gusmão. ${ }^{96}$

\section{CONCLUSÃO}

O espírito de proteção previdenciária que determinou a evolução do instituto da união estável, principalmente na quebra do estigma desonroso que foi dado aos companheiros e companheiras, ao longo da história da humanidade, não se coaduna com o entendimento restritivo dos Tribunais Superiores pátrios, concernente ao não reconhecimento do direito do companheiro, em união estável putativa, ao recebimento de pensão por morte do segurado falecido, na forma de rateio com o cônjuge legítimo, nos regimes públicos de Previdência Social.

A regra de que a denominada união concubinária impura ou adulterina, ainda que putativa, não enseja qualquer tipo de proteção legal, por ser inapta a produzir efeitos jurídicos, deve comportar exceções, precipuamente no campo do Direito Previdenciário.

Isso por que a união estável putativa é um fato social marcado pela postura adotada pelos partícipes no relacionamento, com reflexos entre si e perante a sociedade, que acabam por produzir efeitos jurídicos, ainda que não positivados. Ignorar a existência de famílias paralelas, nas quais um dos integrantes figura como cônjuge em mais de uma família, situação não rara em nossa sociedade, e os efeitos jurídicos dela

${ }^{96}$ GUSMÃO, Paulo Dourado de. Filosofia do direito. Rio de Janeiro: Forense, 2006. p. 91. 
decorrentes, é promover profunda injustiça social e desamparo ao companheiro de boa-fé.

Como deixar à margem da proteção previdenciária $\mathrm{o}$ companheiro putativo exigente do mesmo bem-estar físico, moral e psíquico do cônjuge legítimo? Como reconhecer, no bojo do Estado Democrático de Direito, o retrocesso social na proteção previdenciária ao companheiro putativo, com a consolidação do entendimento jurisprudencial de nossos Tribunais Superiores?

Não é possível, ao aplicador do Direito, negar a própria realidade da vida estampada nas inúmeras famílias paralelas. Ao revés, é preciso promover a integração social do companheiro putativo, com a proteção a quem a merece e procura, posto que a solução para tais casos não pode limitar-se ao mesmo tratamento dado a casos semelhantes no passado, ainda que recente, mas sim estar comprometida com as novas exigências de justiça de uma sociedade que se mostra cada vez mais complexa.

Com efeito, o benefício previdenciário da pensão por morte busca proteger os dependentes do segurado falecido para que não sofram prejuízos econômicos com o risco social gerador do benefício - morte do segurado - definido como evento futuro e incerto.

Torna-se imperativa a tutela do companheiro putativo, uma vez comprovada a verdadeira comunhão de vida, com assistência mútua e de interesses em benefício de ambos, além do estado de boa-fé do concubino como acontece, analogicamente, com o casamento putativo, posto que o Direito deve tratar todos os membros da sociedade como merecedores de "igual respeito e consideração", na lição de Habermas. ${ }^{97}$

$\mathrm{O}$ atual entendimento jurisprudencial dos Tribunais Superiores revela-se uma legitimação autônoma e acrítica da norma posta. É preciso uma dose maior de razoabilidade na interpretação das normas levando em consideração a anormalidade do caso concreto, posto que, na lição de Ávila, "A razoabilidade exige determinada interpretação como meio de preservar a eficácia de princípios axiologicamente sobrejacentes. Interpretação diversa de fato levaria à restrição de algum princípio constitucional, [...]". ${ }^{98}$

${ }^{97}$ HABERMAS, Jürgen. Direito e democracia: entre facticidade e validade. Rio de Janeiro: Tempo Brasileiro, 1997. p. 252.

98 ÁVILA, Humberto. Teoria dos princípios. Da definição à aplicação dos princípios jurídicos. 8. ed., ampl. e atual. São Paulo: Malheiros, 2008. p. 153-154. 
Com efeito, os casos concretos de proteção previdenciária da união estável putativa, não tão raros, devem sem analisados minuciosamente pelo aplicador do direito, diante dos fatos e provas apresentados em Juízo, com sustentação numa hermenêutica comprometida com o sistema de princípios constitucionais, para a construção de uma decisão que se coadune com o ordenamento pátrio, considerado como um todo, ao lado dos valores da ética, da justiça social e da dignidade da pessoa humana nas relações de afeto.

\section{REFERÊNCIAS BIBLIOGRÁFICAS}

ALEXY, Robert. Teoría de los derechos fundamentales. Madri: Centro de Estudios Constitucionales, 1993.

ÁVILA, Humberto. Teoria dos princípios. Da definição à aplicação dos princípios jurídicos. 8. ed., ampl. e atual. São Paulo: Malheiros, 2008.

BARCELLOS, Ana Paula de. A eficácia jurídica dos princípios constitucionais - $\mathrm{O}$ princípio da dignidade da pessoa humana. Rio de Janeiro: Renovar, 2002.

BOBBIO, Norberto. Teoria do ordenamento jurídico. 7. ed. Trad. Maria Celeste Cordeiro Leite dos Santos. Brasília: UnB, 1996.

BONAVIDES, Paulo. Curso de direito constitucional. 9. ed. rev. atual. ampl. São Paulo: Malheiros, 2000.

BORGES, Mauro Ribeiro. Previdência funcional. 1. ed., 2. Tiragem. Curitiba: Juriá, 2007.

BRIGUET, Magadar Rosália Costa; VICTORINO, Maria Cristina Lopes; HORVATH JÚNIOR, Miguel. Previdência social: aspectos práticos e doutrinários dos regimes jurídicos próprios. São Paulo: Atlas, 2007.

CANOTILHO, Joaquim José Gomes. Direito constitucional e teoria da constituição. Coimbra: Livraria Almedina, 1998.

COIMBRA, Feijó. Direito previdenciário brasileiro. 9. ed. Rio de Janeiro: Trabalhistas, 1998.

DWORKIN, Ronald. Levando os direitos a sério. São Paulo: Martins Fontes, 2002.

Uma questão de princípio. Trad. Luis Carlos Borges. 2. ed. São Paulo: Martins Fontes, 2005.

O império do direito. 2. ed. São Paulo: Martins Fontes, 2007. 
ESPÍNDOLA, Ruy Samuel. Conceito de princípios constitucionais. São Paulo: Revista dos Tribunais, 1999.

FARIAS, José Fernando de Castro. A origem do direito de solidariedade. Rio de Janeiro: Renovar, 1998.

GUSMÃO, Paulo Dourado de. Filosofia do direito. Rio de Janeiro: Forense, 2006.

HABERMAS, Jürgen. Direito e democracia: entre facticidade e validade. Rio de Janeiro: Tempo Brasileiro, 1997.

HOVARTH JÚNIOR, Miguel. Direito previdenciário. 3. ed. São Paulo: Quartier Latin, 2003.

LEIRIA, Maria Lúcia Luz. Direito previdenciário e estado democrático de direito: uma (re)discussão à luz da hermenêutica. Porto Alegre: Livraria do Advogado, 2001.

LEITE, Eduardo de Oliveira. Direito de família. São Paulo: RT, 2005. v. 5.

MARTINEZ, Wladimir Novaes. Princípios de direito previdenciário. 4. ed. São Paulo: LTr, 2001.

OLIVEIRA, Marcelo Andrade Cattoni de Oliveira. Crise e desafios da constituição: perspectivas críticas da teoria e práticas constitucionais brasileiras. In: SAMPAIO, José Adércio Leite (Coord). Jurisdição constitucional e direitos fundamentais. Belo Horizonte: Editora Del Rey, 2003.

PEREIRA, Rodrigo da Cunha. Concubinato e união estável. 7. ed. rev. e atual. Belo Horizonte: Del Rey, 2004.

PESSOA, Claudia Grieco Tabosa. Efeitos patrimoniais do concubinato. São Paulo: Saraiva, 1997.

PIANOVSKI, Carlos Eduardo. Famílias simultâneas e monogamia em família e dignidade humana. In: CONGRESSO BRASILEIRO DE DIREITO DA FAMÍLIA, 5, 2006, São Paulo. Anais do V Congresso Brasileiro de Direito de Família. São Paulo: IOB Thomson, 2006.

PINHEIRO, Vinicius Carvalho. A experiência brasileira. In: Reformas dos Sistemas de Pensão na América Latina. MPAS, Coleção Previdência Social, 2001, v. 12.

PIRES, Maria da Graça M. S. Soromenho. O concubinato no direito brasileiro. Rio de Janeiro: Forense, 1998.

ROCHA, Leonel Severo. Epistemologia jurídica e democracia. São Leopoldo: Unisinos, 1998. 
RODRIGUES, Silvio. Direito Civil. 27. ed. São Paulo: Saraiva, 2002, v. 6.

SARLET, Ingo Wolfgang Sarlet. O direito fundamental à moradia na Constituição: algumas anotações a respeito de seu contexto, conteúdo e possível eficácia. In: SAMPAIO, José Adércio Leite (Coord). Jurisdição constitucional e direitos fundamentais. Belo Horizonte: Editora Del Rey, 2003.

TAVARES, Marcelo Leonardo. Previdência e assistência social. Legitimação e fundamentação constitucional brasileira. Rio de Janeiro: Lúmen Júris, 2003.

VELOSO, Zeno. União Estável. Doutrina, legislação, direito comparado, jurisprudência. Pará: Cejup, 1997.

VIANA, Marco Aurélio S. Da união estável. São Paulo: Saraiva, 1999.

VIEIRA, Oscar Vilhena. A constituição e sua reserva de justiça (um ensaio sobre os limites materiais ao poder de reforma). São Paulo: Malheiros, 1999.

WALD, Arnoldo. Direito Civil: Direito de Família. 17. ed. São Paulo: Saraiva, 2009. 


\title{
AS REFORMAS EXISTENTES NOS SISTEMAS DE APRECIAÇÃO DAS PROVAS NO JUÍZO CRIMINAL
}

\author{
Hamilton da Cunha Iribure Júnior
}

ISSUE DOI: $10.21207 / 1983.4225 .269$

\section{RESUMO}

O objetivo do presente trabalho é realizar uma leitura crítica dos principais pontos que delimitam os sistemas de avaliação da prova no juízo criminal. A análise da prova da alegação de um fato sempre permeou as relações sociais e, principalmente, as existentes em matéria de processo. Não se trata de uma tarefa fácil, tendo em vista que a questão extrapola a esfera do direito processual para atingir a órbita de outras áreas do conhecimento humano, vez que há uma estrita relação entre o que se avalia e quem se avalia. A prova é concebida como uma reconstrução de um fato ocorrido, de um evento que carece de comprovação. E tal se faz para que se forme um convencimento, que seja possível analisar não somente o que de fato ocorreu, mas a possibilidade de aferição de responsabilidade criminal ao acusado da prática do fato. Dessa forma, na presente abordagem, utiliza-se o método analítico documental. Uma das conclusões possíveis é a de que, apesar de toda a tecnologia que cerca a temática atualmente, não se conseguiu, ainda, desvencilhar-se do caráter da subjetividade da análise judicial, tendo em vista que não se trata somente de aferir um dado técnico, mas de, efetivamente, julgar um ser humano.

Palavras-chave: Dignidade Humana. Prova. Sistemas. Avaliação. Processo Penal.

\section{INTRODUÇÃO}

